\title{
U.S. Weakness and the Struggle for Hegemony
}

\section{IMMANUEL WALLERSTEIN}

I am going to start with two things with which I think nearly all MR readers will probably agree. One, imperialism is an integral part of the capitalist world-economy. It is not a special phenomenon. It has always been there. It always will be there as long as we have a capitalist world economy. Two, we are experiencing at the moment a particularly aggressive and egregious form of imperialism, which is now even ready to claim that it is being imperialist.

Now, I ask you to reflect upon that anomaly. How do we explain that, at the moment, we are living through a particularly aggressive and egregious form of imperialism, which for the first time in over a hundred years has been ready to use the words imperial and imperialism? Why should they do that? Now, the answer most people give in one word is U.S. strength. And the answer I will give in one word is U.S. weakness.

We have to start in 1945, when the United States became hegemonic, really hegemonic. What does hegemony in this context mean? It means that the U.S. nation-state was so much the strongest, it had an economic capability so far ahead of anybody else in the world as of 1945, that it could undersell anyone in their own home markets. The United States had a military strength that was unparalleled. As a consequence, it had an ability to create formidable alliances, NATO, the U.S.-Japan Defense Pact, and so on. At the same time, the United States, as the hegemonic power, became culturally the center of the world. New York became the center of high culture and American popular culture went on its march throughout the world.

The first time I was in the Soviet Union, in the Brezhnev era, my host took me to a nightclub in Leningrad. The one thing that startled me in the Soviet Union, the whole time I was there, was that in this nightclub one heard American popular music sung in English. And, of course, ideologically, I

Im MANUEl WALLeRSTEIN (1930-2019) was the director of the Fernand Braudel Center for the Study of Economies, Historical Systems, and Civilizations; the editor of Review; and Senior Research Scholar at Yale University. He was the author of numerous books, including Transforming the Revolution: Social Movements and the World-System, cowritten with Andre Gunder Frank, Giovanni Arrighi, and Samir Amin (Monthly Review Press, 1990).

Wallerstein was also a frequent contributor to Monthly Review. "U.S. Weakness and the Struggle for Hegemony” was first published in Monthly Review 55, no. 3 (July-August 2003). 
think we underestimate the degree to which the theme of the "free world" has had legitimacy among wide segments of the world population.

So the United States was really on top of the world for about twenty-five years, and it got its way in whatever it wanted to do.

It is true that there was the Soviet Union, which posed a military difficulty for the United States. Nonetheless, the United States handled that very simply by an agreement. It is called Yalta, which encompasses more than just what happened at Yalta itself. I think the left has underestimated historically the reality and the importance of the Yalta agreement that made the Cold War a choreographed arrangement in which nothing ever really happened for forty years. That was the important thing about the Cold War. It divided up the world into the Soviet zone that was about a third of the world, and the U.S. zone that was two-thirds. It kept the zones economically separate and allowed them to shout at each other loudly in order to keep their own side in order, but never to make any truly substantial changes in the arrangement. The United States was therefore sitting on top of the world.

This lasted only about twenty-five years. The United States ran into difficulty somewhere between 1967 and 1973 because of three things. One, it lost its economic edge. Western Europe and Japan became sufficiently strong to defend their own markets. They even began to invade U.S. markets. They were then about as strong and as competitive as the United States economically and that, of course, had political implications.

Secondly, there was the world revolution of 1968 in which many MR readers were involved, in one way or another. Think of what happened in 1968. In 1968, there were two themes that were repeated everywhere throughout the world in one version or another. One, we don't like the U.S. hegemony and dominance of the world, and we don't like Soviet collusion with it. That was a theme everywhere. That was not only the Chinese stance on the two superpowers but that of most of the rest of the world as well.

The second thing that 1968 made clear was that the Old Left, which had come to power everywhere - Communist parties, social-democratic parties, and national liberation movements - had not changed the world and something had to be done about it. We were not sure we trusted them anymore. That undermined the ideological basis of the Yalta agreement, and that was very important.

The third thing that happened is that there were people who didn't agree with Yalta. They were located in the third world and there were at least four significant defeats of imperialism that occurred in the third world. The first was China, where the Communist Party defied Stalin and marched on Kuomintang-controlled Shanghai in 1948, thus getting China out from under U.S. influence on the mainland. That was a central 
defeat in the U.S. attempt to control the periphery. Secondly, there was Algeria and all its implications as a role model for other colonial territories. There was Cuba, in the backyard of the United States. And finally, there was Vietnam, which both France and then the United States were incapable of defeating. It was a military defeat for the United States that has structured world geopolitics ever since.

The threefold fact of the rise of economic rivals, the world revolution of 1968 and its impact on mentalities across the world, and Vietnam's defeat of the United States, all taken together, mark the beginning of the decline of the United States.

How could the rulers of the United States handle the loss of hegemony? That has been the problem ever since. There were two dominant modes of handling this loss of hegemony. One is that pursued from Richard Nixon through Bill Clinton, including Ronald Reagan, including George Bush Sr. All these U.S . presidents handled it the same way, basically a variant of the velvet glove hiding the mailed fist.

They sought to persuade Western Europe and Japan and others that the United States could be cooperative; that the others could have an alliance of semi-equals, though with the United States exerting "leadership." That's the Trilateral Commission and the G7. And, of course, they were using all this time the unifying force of opposition to the Soviet Union.

Secondly, there was the so-called Washington Consensus that coalesced in the 1980s. What was the Washington Consensus about? I remind you that the 1970s was the era when the United Nations proclaimed the decade of development. Developmentalism was the name of the game from the 1950s through the 1970s. Everybody proclaimed that countries could develop. The United States proclaimed it. The Soviet Union proclaimed it, and everybody in the third world proclaimed it -if only a state were organized properly. Of course, people disagreed about how to organize a state properly, but if only it were organized properly and did the right things, it could develop. This was the basic ideology; development was to be achieved by some kind of control over what went on within sovereign national states.

Now, the Washington Consensus was the abandonment and the denigration of developmentalism, which had visibily failed by the late 1980s, and, therefore, everybody was ready to abandon. They substituted for developmentalism what they called globalization, which simply meant opening up all the frontiers, breaking down all the barriers for: (a) the movement of goods and, more importantly, (b) capital, but not (c) labor. And the United States set out to impose this on the world.

The third thing they did along this line of "cooperation" was an ideological consensus-building process at Davos. Davos is not unimportant. 
Davos was an attempt to create a meeting ground of the world's elites, including elites from the third world, and constantly bring together and blend their political activity.

At the same time, the objectives of the United States during this period took three forms. One was to launch a counteroffensive. It was a counteroffensive of neoliberalism on three levels to: (1) reduce wages worldwide; (2) reduce costs for (and end ecological constraints on) corporations, permitting the total externalization and socialization of such costs; and (3) reduce taxation, which was subsidizing social welfare (that is to say, subsidizing education, health care, and lifelong guarantees of income).

On all these three levels they were only partially successful. None of these three succeeded totally, but they all succeeded a little. However, cost curves were not brought down to anything like the 1945 level. The cost curves had gone way up and they are down now, but they are not down below the 1945 level, and they will go up again.

The second objective was to deal with the military threat. The real threat to U.S. military power, and they say it all the time, so let's believe them, is nuclear proliferation; because if every little country has nuclear weapons it becomes very tricky for the United States to engage in military action. That is what North Korea is demonstrating at this moment. North Korea only has two nuclear bombs, if what the newspapers say is correct. But that is enough to shake things up.

The third objective - and this was very crucial and they've been working at it since the 1970s - was to stop the European Union. The United States was for the European Union in the 1950s and 1960s, when it was a means of getting France to agree to have Germany rearm. But once it became serious it was viewed as an attempt to create a European state of one variety or another, and the United States was of course strongly opposed to it.

What happened? First, we had the collapse of the Soviet Union. That was a disaster for the United States; it removed the most important political weapon they had in relation to Western Europe and East Asia.

Second, there was Saddam. Saddam Hussein started the first Gulf War. He did it deliberately. He did it deliberately to challenge the United States. He could not have done that if the Soviet Union had still been an active power. They would have stopped him from doing it because it would have been too dangerous in terms of the Yalta agreement. And he got away with it. That is to say, at the end of the war, all he lost was what he had gained. He was back at the starting point. That is what has stuck in the craw for ten years. That war was a draw. It was not a victory for the United States.

Third, we saw in the 1990s, to be sure, a momentary spurt of the U.S. economy, but not of the world-economy as a whole and a spurt that is 
now over. But we now have a weakening of the dollar, and the dollar has been a crucial lever of the United States, enabling it to have the kind of economy it has and the dominance it has over the rest of the world. And finally, we had 9/11 that showed that the United States was vulnerable.

Enter the hawks. The hawks do not see themselves as the triumphant continuation of U.S. capitalism or U.S. power or anything else. They see themselves as a group of frustrated outsiders who for fifty years did not get their way even with Reagan, even with Bush Sr., even with George Bush Jr. before 9/11. They are still worried that Bush Jr. will chicken out on them. They think that the policy that went from Nixon to Clinton to the first year of George W. Bush, of trying to handle this situation, diplomatically, multilaterally - I call it the velvet glove - was an utter failure. They think it just accelerated the decline of the United States and they think that had to be changed radically by engaging in an egregious, overt, imperial action - war for the sake of war. They did not go to war on Iraq or Saddam Hussein because he was a dictator. They did not go to war on Iraq even for oil. I will not argue that point here, but they did not need the war on Iraq for oil. They needed it to show the United States could do it, and they needed that demonstration in order to intimidate two groups of people: (1) anybody in the third world who thinks that they should engage in nuclear proliferation; and (2) Europe. This was an attack on Europe, and that is why Europe responded the way it did.

I wrote an article in 1980 in which I said, "It is geopolitically inevitable that over the next period, there will emerge a Paris/Berlin/Moscow alliance." I said this when the Soviet Union was still in existence and I have repeated it ever since. Now, everybody talks about it. There is actually a website now, paris-berlin-moscou.info, which reprints what people are writing in French, German, Russian, and English throughout Europe about the virtues of a Paris/Berlin/Moscow linkup.

We must not underestimate the second Security Council nonvote in March of this year. It is the first time since the United Nations was founded that the United States, on an issue that mattered to it, could not get a majority on the Security Council. Of course, they have had to veto various resolutions in the past but on no issue that was truly crucial to them. But in March 2003 they withdrew the resolution because they could not get more than four votes for it. It was a political humiliation and it was universally regarded as such. The United States has lost legitimacy, and that is why you cannot call it hegemonic anymore. Whatever you want to call it, there is no legitimacy now and that's crucial.

So, what should we look for in the next ten years? First, there is the question of how Europe will construct itself. It will be very difficult, but 
they will construct themselves and they will construct an army. Maybe not all of Europe, but the core. The United States is really worried about it, and that army will sooner or later link up with the Russian army.

Second, look at North East Asia. This is harder but I think China, a reunited Korea, and Japan will begin to move together politically and economically. Now, this will not be easy. The reunification of Korea will be a tremendously difficult thing to achieve. The reunification of China as well will be a difficult thing to achieve, and those countries have all sorts of reasons for hating one another and tensions with deep historical roots, but the pressure is on them. If, realistically, they are going to survive as independent forces in the world, they will move in this direction.

Thirdly, you should watch the World Social Forum. I think that is where the action is. It is the most important social movement now on the face of the earth and the only one that has a chance of playing a really significant role. It has blossomed very fast. It has a wealth of internal contradictions that we should not underestimate and it will run through all sorts of difficult periods, and it may not make it. It may not survive as a movement that is a movement of movements, that has no hierarchical center, is tolerant of all the varieties within it and yet stands for something. This is not an easy game, but it is where the best hope lies.

Finally, I would think you ought to look at the internal contradictions among capitalists. The basic political contradiction of capitalism throughout its history has been that all capitalists have a common political interest insofar as there is a world class struggle going on. At the same time, all capitalists are rivals of all other capitalists. Now that is a fundamental contradiction of the system and it's going to be very explosive.

I don't think we should underestimate the fact that in April 2003 Lawrence Eagleberger, the secretary of state under the first President Bush, and still a close adviser of the current president's father, said in print that if the United States were now to invade Syria, he, Eagleberger, would be for impeaching George W. Bush. Now, that is not a very light thing for a person of that sort to say. So there is a message being sent, and who is the message coming from? I think it is coming from the father for one thing. And beyond that, it is coming from an important segment of U.S. capital and of world capital. They are not all happy about the hawks. The hawks have not won the game. They have grabbed hold of the U.S. state machinery; 9/11 made that possible. And the hawks know it is now or never and they will continue to push, because if they don't push forward, they will fall back. But they have no guarantee of success, and some of their biggest enemies are other capitalists who do not like the line with Europe and Japan because they basically do believe in the unity 
of capital; who don't think that the way you handle these things is by smashing all opposition, but would prefer to co-opt it. They are extremely worried that this is Samson pulling down the house.

We have entered a chaotic world. It has to do with the crisis of capitalism as a system, but I will not argue that now. What I will say is that this chaotic world situation will now go on for the next twenty or thirty years. No one controls it, least of all the U.S. government. The U.S. government is adrift in a situation that it is trying to manage all over the place and that it will be incapable of managing. This is neither good nor bad, but we should not overestimate these people nor the strength on which they rely.

\section{MONTHLY REVIEW Fifty Years Ago}

The more the giant monopolistic corporations conglomerate and multinationalize, the further removed their top managements become from any particular product or production process. The concerns of headquarters are purely financial, i.e., profit- and accumulation-oriented; while matters of production, technology, etc., are relegated to the division, subsidiary, and plant managers who are responsible for producing and even to a large extent selling the corporation's many products.... The multinational corporation, in brief, is the key institution of finance capital in the second half of the 20th century; and Lenin's characterization in Imperialism (1917) requires little modification to fit it: "The concentration of production; the monopolies arising therefrom; the merging or coalescence of the banks with industry - such is the history of the rise of finance capital and such is the content of this term."

- Harry Magdoff and Paul M. Sweezy, "Notes on the Multinational Corporation," Part Two, Monthly Review, November 1969 